\title{
PHYSICAL WORK CAPACITY OF YOUNG GRECO-ROMAN WRESTLERS ON THE BACKGROUND OF THEIR SOMATIC DEVELOPMENT
}

\author{
Wladyslaw Jagiello, Wlodzimierz Tkaczuk \\ Academy of Physical Education, Warsaw, Poland
}

\begin{abstract}
Wladyslaw Jagiello. Doctor, head of Department of Heavy Athletics at Warsaw Academy of Physical Education. The field of scientific research - long-term training and direct preparation to the competition.
\end{abstract}

\begin{abstract}
On the basis of studies of 210 Greco-Roman wrestlers aged 11-18 the impact of training loads and sports selection in the above sports event upon physical development and general work capacity of young athletes have been determined.

Besides, age dynamics of changes of the major somatic indices (body length and mass) as well as physical work capacity at the stage of initial and basic sports preparation has been determined.

The studies have resulted in the determination of specific for Greco-Roman wrestlers changes in the examined indices and development of evaluation scale of general physical work capacity.

On the basis of findings we may conclude that Greco-Roman wrestling has a positive influence on developing body. In most cases mean values of examined somatic indices exceed those of children not engaged in sports as well as children practising other sports events. This sports event may be considered as a good means stimulating physical development of children and youth.

The age of 11-15 has turned to be the period of the greatest structural and functional changes in their ontogenesis. During this period the greatest rate of development is peculiar for body mass and height (11-12 years - mass $16 \%$, length 6\%; 14-15 years - mass 25\%, length 6\%), whereas development of work capacity occurs evenly. Along with relative stabilization of the rate of body mass and height development beginning from the age of 16 high rate of work capacity development is observed.
\end{abstract}

Keywords: Greco-Roman wrestling, somatic development, performance abilities.

\section{INTRODUCTION}

I $\mathrm{n}$ the process of an athlete's preparation for competitions and achievement of high sports level of crucial importance is the information about his body responses to the given training loads and their modifications which allow achievement of maximum results. Training of Greco-Roman wrestlers has an impact upon all motor qualities, increases strength, endurance, speed, flexibility and agility.

Under the influence of physical loads morphological and functional changes occur in organs and systems of the body, central and intrasystem regulation determining the level of body's resistance and its adaptation improves (Płatonov, 1990; Jagiełło, 2000 a). Along with improvement of technical and tactical mastery as

well as mental stability significant increase of physical work capacity is observed (Astrand, 1986, 1992). That is why, one should pay special attention to the character of changes in general work capacity determining not only the level of one's potential but the health level of an athlete above all. This is especially important during the period of biological development (Laskowski, Czerwienski, 1997; Jagiełło, 2000 b).

Our studies have been based upon suggestion that changes in general work capacity and somatic development of youth engaged in Greco-Roman wrestling may be significantly differentiated as compared to both the youth not engaged in regular sports training and athletes of different sports events. 
The main cognitive objective of the work consists in solving the following question: is the linear increase of general physical work capacity of young wrestlers characteristic in the long-term aspect, or are there periodic oscillations which could be linked with somatic development determined by ontogenesis dynamics?

The objective on the whole has been to design estimation scale for general work capacity of young Greco-Roman wrestlers on the basis of obtained empirical data.

\section{MATERIAL AND METHODS}

Measurement of general work capacity. Although the most widely used means of work capacity level determination is the method of measurement of oxygen threshold, due to some difficulties of organizational and methodical character during maximum work of athletes (especially children) we were to use fast and simple method - modification of Harvard StepTest (Wołkow, 1997). It allows fast diagnostics of even great number of athletes without any intervention into training process.

The load in this test consisted in ascending a step during $5 \mathrm{~min}$. During the test the subjects ascended gymnastic bench ( $30 \mathrm{~cm}$ height) at a pace of 30 ascents per minute.

Before the test the subjects were acquainted with the techniques of its execution. Before the work resting heart rate (HR) was measured in a sitting position (during $30 \mathrm{~s}$ ).

After testing the subjects had a rest in sitting position. Beginning from the second minute of rest HR was measured three times (in $30 \mathrm{~s}$ intervals): from 60 to $90 \mathrm{~s}$, from 120 to $150 \mathrm{~s}$, and from 180 to $210 \mathrm{~s}$. Results of measurements were put into protocol. HR was also measured just after the load.

Results of testing are represented in conventional units in the form of index of Harvard Step-Test (IHST). Its value has been determined according to the formula:

$$
\operatorname{IHST}=\frac{t \cdot 100}{(f 1+f 2+f 3) \cdot 2},
$$

when:

$\mathrm{t}$ - real time of work in s;

$(\mathrm{f} 1+\mathrm{f} 2+\mathrm{f} 3)-$ sum of HR in the first $30 \mathrm{~s}$ of each minute (beginning from the second);

number 100 necessary to represent IHST in complete units; number $2-$ to re-count sum of HR per minute.
Anthropometric measurements. Body length was measured from the highest point on the head (vertex) as the upper limit to the level of platform of balance as the lower limit. Measurement was conducted in vertical axis of the body.

Balance was used to measure body mass. During measurements the subjects were in shorts only. Studies were conducted in accordance with generally applied procedures (Drozdowski, 1984).

Statistical methods. Standard statistical methods were used. Microsoft Excel XP programme was used for data processing. The following indices were determined: arithmetical mean (x), standard deviation (Sx), coefficient of variation $(\mathrm{V})$, standard mean error $(\mathrm{m})$ as well as coefficient of correlation (r).

Age dynamics was determined on the basis of annual increases according to the formula:

$$
\mathrm{T}=\frac{100\left(\mathrm{P}_{2}-\mathrm{P}_{1}\right)}{0.5\left(\mathrm{P}_{1}+\mathrm{P}_{2}\right)} \%,
$$

when:

$\mathrm{P}_{1}$ - initial result;

$\mathrm{P}_{2}$ - final result;

$\mathrm{T}-$ value of increase.

Standardization criteria. During arrangement of standard values of general work capacity measured by Index of Harvard Step-Test ranges based upon standard deviation of arithmetical mean have been used (Ferguson, Takane, 1997). The following levels of evaluation have been utilized:

1. Very high $->\mathrm{x}+1 \mathrm{Sx}$,

2. High - from $\mathrm{x}+0.5 \mathrm{Sx}$ to $+1 \mathrm{Sx}$,

3. Moderate - from $\mathrm{x}+0.5 \mathrm{Sx}$ to $\mathrm{x}-0.5 \mathrm{Sx}$,

4. Low - from $\mathrm{x}-0.5 \mathrm{Sx}$ to $\mathrm{x}-1 \mathrm{Sx}$,

5 . Very low $-<\mathrm{x}-1 \mathrm{Sx}$.

210 skilled Greco-Roman wrestlers representing two provinces of Poland: Mazovetsky ("Legia Warszawa" "Budowlanka Radom", "SMS Radom", "Orzel Wierzbica", "WLKS Siedlce" and Ljublin ("Orleta Lukow", "AGROS Zamosc", Grezowia Grezowka", "UKS Trzebieszow") took part in the studies. Age of subjects was in the range of $11-18$ years. They have been training for $1-8$ years.

Most of wrestlers were at the age of 14 $(\mathrm{n}=52)$. Body mass of subjects has ranged from 25 to $95 \mathrm{~kg}$, whereas body length — from 125 to 
$190 \mathrm{~cm}$. All subjects obtained the written consent of a physician for participation in the studies.

\section{RESULTS}

Changes of wrestlers' general work capacity. Results of physical studies are presented in Fig. 1.

Mean values of resting $H R$ are rather high (except for athletes aged 18) and change with age. The highest values of HR have been observed in wrestlers aged 14 and 15 . The above may be due to the so-called pre-start response - excitation of central nervous system before expected work (Matwiejew, Jagiełło, 1997).

High level of HR just after the load as well as during the 1, 2, and 3 min of the recovery has been characterized by significant variability. The highest level of HR just after the load has been revealed in athletes aged 16 and 14, whereas the lowest - in those aged 13 and 17. HR indices during the recovery period decrease with age which is indicative of adaptation capacity development in response to physical loads.

Age dynamics of IHST is presented in Table 2. Constant index increase is observed with age up to 18 years. From 11 to 16 years annual index increase constitutes $1.2-3.2 \%$. After the age of 16 rapid increase of index is observed which constitutes 7.8 and $10.1 \%$ at the age of $16-17$ and $17-18$, respectively. The highest value is
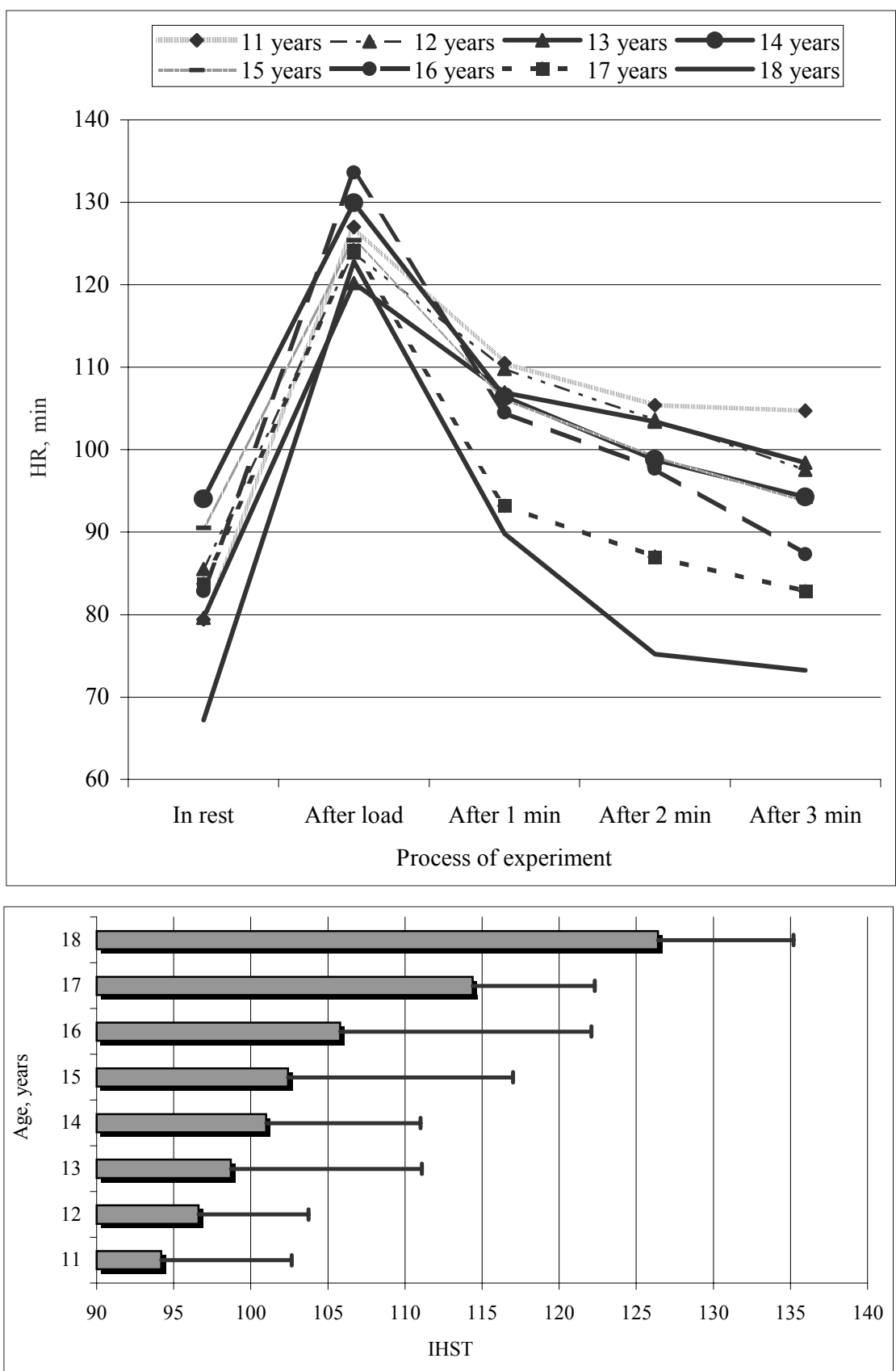

Fig. 1. Cardiovascular system response to the load of Harvard Step-Test in Greco-Roman wrestlers
Fig. 2. Age dynamics of general work capacity of Greco-Roman wrestlers (expressed by Index of Harvard StepTest (IHST)) 
observed at the age of $18-126.4 \mathrm{CU}$.

Standard requirements of general work capacity of young wrestlers. Arrangement of standard values of general work capacity (expressed by Harvard Index) has been based on standard deviation from arithmetical mean (Ferguson, Takane, 1997) for three age groups: $11-13,14-16$ and $17-18$ years.

Taking the above into consideration an estimation scale allowing relatively objective diagnostics of the state of body of young wrestlers has been elaborated (Table).

Objective estimation of general work capacity of young wrestlers should assist in determination of the reserve for further individual development and achievement of high level of sports mastery. Besides, it plays an important role in selection of the most efficient means and methods of training process.

Dynamics of somatic development. Body length is a stable quality; only the long-term impact of a definite factor can significantly influence changes of this quality in individual development. Obtained data of anthropometric measurements (body length and mass) indicate a natural biological development of young wrestlers. Fig. 3 illustrates age dynamics of body length.
Progressive dynamic increase of index is observed until the age of 16 , afterwards it stabilizes. Maximum annual increase is observed at the age of $14-15(6.2 \%)$ and $11-12(5.7 \%)$. During other time intervals an even increase is noted (annual increase constitutes approximately $2-3 \%)$.

Body mass is characterized by significant variability. According to the above feature the subjects represent heterogeneous group. The highest annual increase of the above index has been noted at the age of $11-12(14.2 \%)$ and 14 $15(25.4 \%)$.

Although in our studies mean values of body mass of athletes aged 13 have been $4.8 \%$ lower as compared to those aged 12 , there is no reason to say about natural age decrease of body mass. Revealed trend in development of body mass of wrestlers aged $12-13$ needs further verification. This result may be influenced by numerous factors, such as selection of subjects, sports event specifics (13-year-old athletes are allowed to participate in competitions; the lowest weight category is that of $29-32 \mathrm{~kg}$ ).

Roufier's index changes irregularly with age (Fig. 5). Changes are of expressed wave-like character. It decreases at the age of $11-13$,
Table. Estimation of general work capacity of young Greco-Roman wrestlers

\begin{tabular}{|c|c|c|c|}
\hline Levels & $11-13$ years & $14-16$ years & $17-18$ years \\
\hline Very high & $106.7>$ & $117>$ & $130.6>$ \\
\hline High & $101.6-106.6$ & $110.5-116.9$ & $125.5-130.5$ \\
\hline Moderate & $91.4-101.5$ & $97.6-110.4$ & $115.3-125.4$ \\
\hline Low & $86.3-91.3$ & $91.2-97.5$ & $110.2-115.2$ \\
\hline Very low & $86.2<$ & $91.1<$ & $110.1<$ \\
\hline
\end{tabular}

Fig. 3. Age dynamics of body length of Greco-Roman wrestlers $(n=210)$

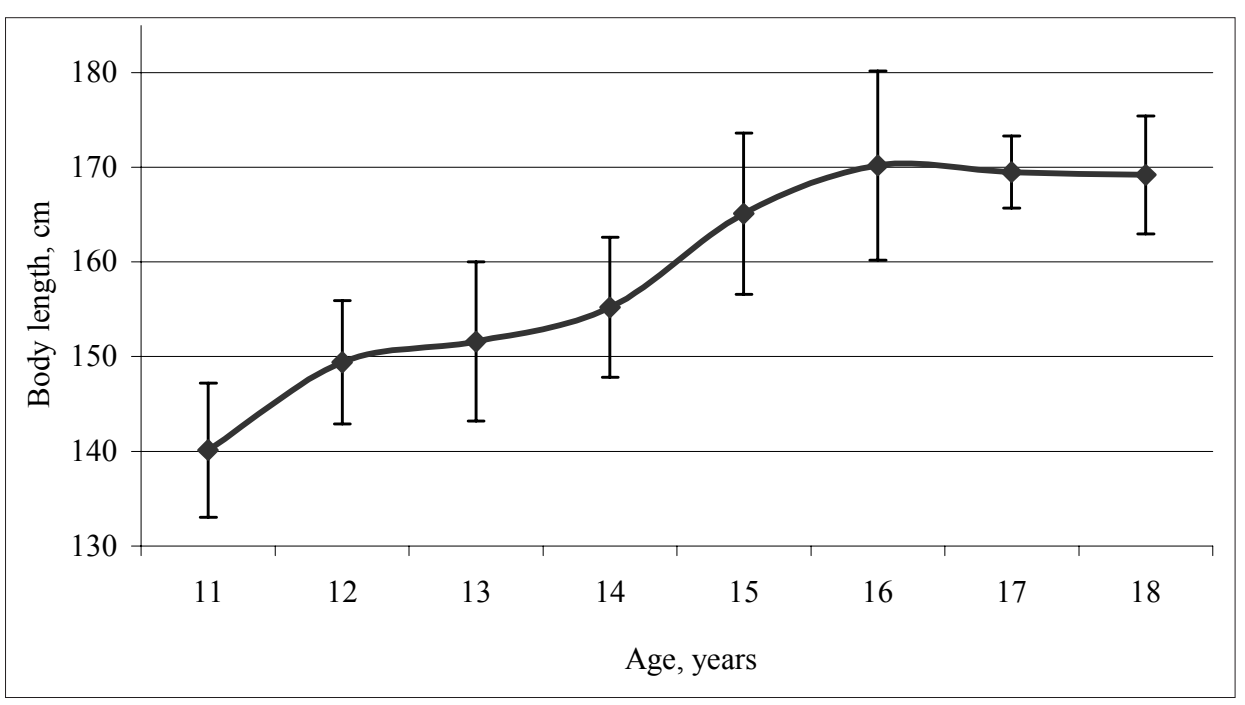




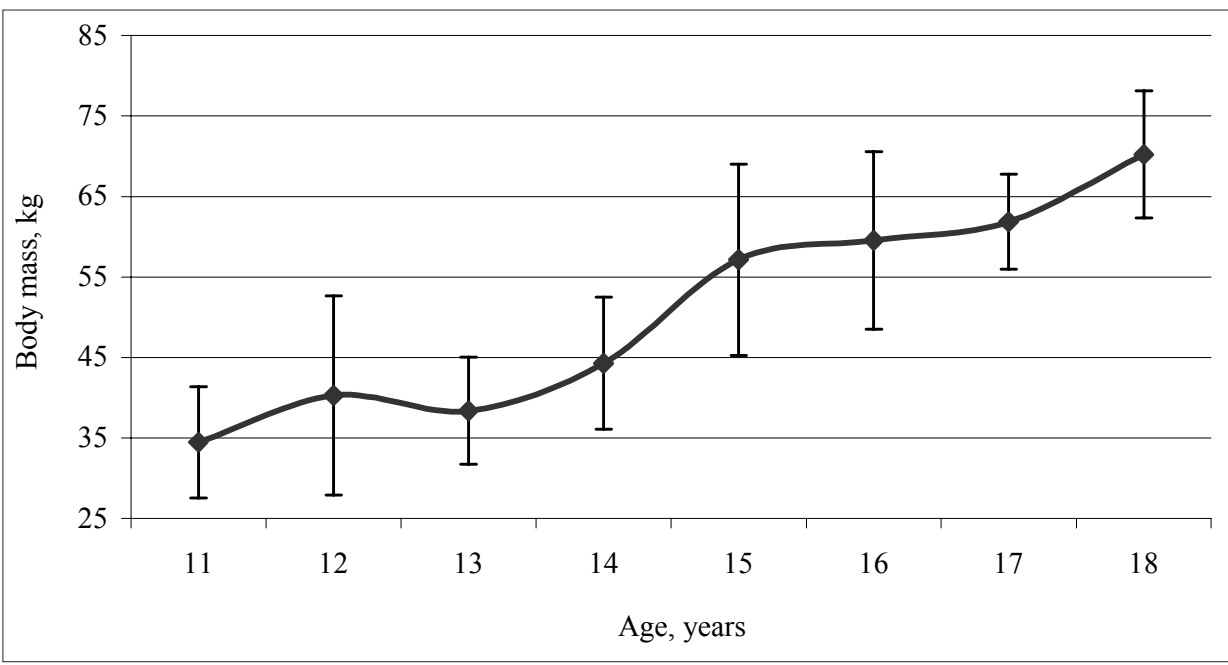

Fig. 4. Age dynamics of body mass of Greco-Roman wrestlers $(n=210)$

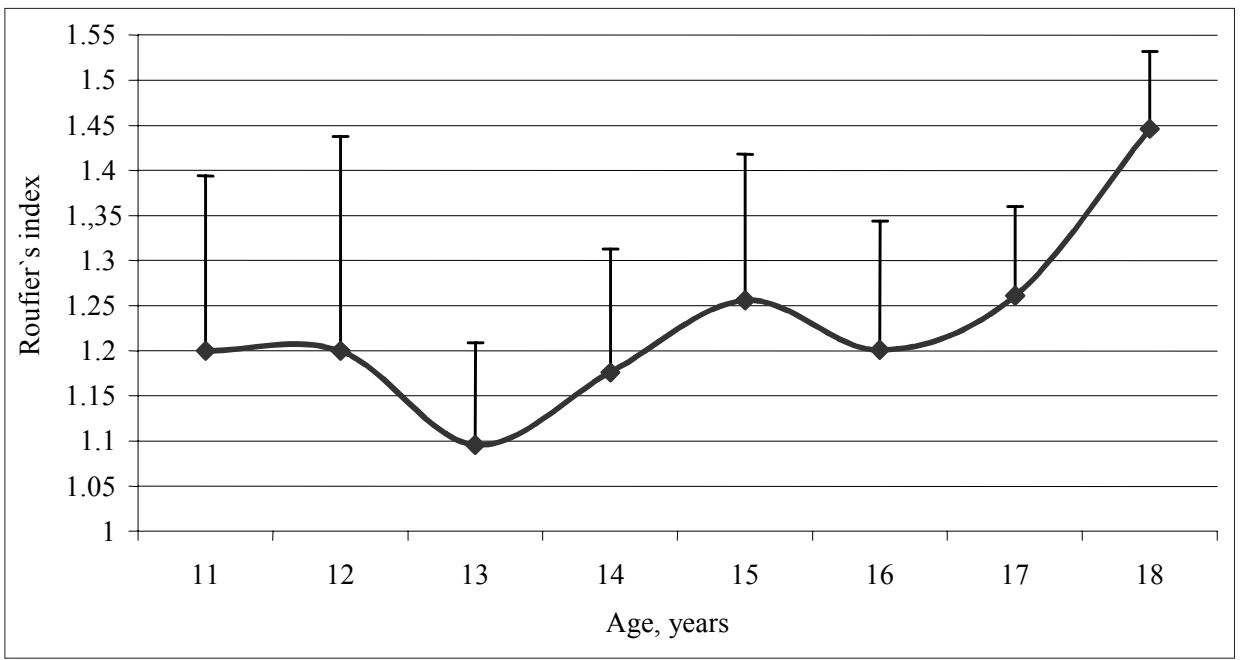

Fig. 5. Age dynamics of body mass of Greco-Roman wrestlers' (n=210) Roufier's index

whereas at the age of $13-15$ the tendency of index increase is observed. At the age of 15-16 another decline is noted whereas beginning from the age of 16 constant increase is observed. Maximum values are attained at the age of $17-18$.

Taking into account somatotype classification according to Roufier's index one may state that before 16 years of age young wrestlers have a leptosomatic type of body build whereas beginning from the age of 17 - athletic one. Taking into account the above tendency as well as the fact that coefficient of variation of index significantly decreases with age $(19 \%$ - at the age of 11 and $5 \%$ - at the age of 18$)$, one may assume that long-term training loads have a tremendous influence upon the type of body build of wrestlers.

\section{DISCUSSION}

Numerous authors studied general work capacity with utilization of Harvard Step-Test
(Astrand, 1986; Fibak et al., 1993; Wołkow, 1997, Jagiełło, 2000 b; Jagiełło et al., 2002).

Long-term studies of great population of children and youth (Berger et al., 1990) indicate rather high age variations in general work capacity of boys. Studies of other authors (Burdukiewicz et al., 1997) have shown that the lowest values of Harvard's index are observed at the age of 11 which is characterized by relatively great increase in body mass and length. Then above phenomenon has been confirmed by our studies of wrestlers: $11-12$ years of age is the period during which one may observe rather significant increase in body mass (15.5\%) and body length $(5.7 \%)$ while the level of Harvard Step-Test remains the lowest.

Studies of the group of judokas (Jagiełło, $2000 \mathrm{~b})$ demonstrate that intensive increase of body length and mass at the age of $11-12$ is associated with decreased general work capacity. Despite similarity between judo and GrecoRoman wrestling age dynamics of work capacity 
of judokas differs from that of Greco-Roman wrestlers. Beginning from the age of $12-13$ the level of work capacity in judokas increases, during the period of $13-15$ years it stabilizes, whereas since 15 years of age an even and gradual increase occurs. In Greco-Roman wrestlers a constant and relatively even increase of general work capacity occurs with age and experience.

The results of conducted studies demonstrate that physical loads applied in training process of young Greco-Roman wrestlers have a favorable effect on the development of their functional capacities.

As regards the studies of body length and mass of Polish youth (Trzesniowski, 1990; Asienkiewicz, 1999), we may state that young Greco-Roman wrestlers excel their peers in all age groups both in body mass and length. It should be also outlined that children from eastern regions of Poland significantly excel rural youth (ŁaskaMierzejewska, 1999; Berger et al., 1990).

Comparison of the results of somatic indices of young Greco-Roman wrestlers with standards for Polish children (Trzesniowski, 1990) indicates a positive influence of training means upon physical development of children because at the age of $11-16$ they excel their peers not engaged in sports. After the age of 16 a relative stabilization of body length along with simultaneous increase of body mass is observed.

Boys engaged in wrestling are much taller than gymnasts (Karosz, 1993) and slightly (differences are statistically insignificant) shorter and lighter than judokas (Jagiełło, 2000 b). They are significantly shorter than track and field athletes specialized in speed and strength events, such as shot putting, javelin and discus throwing (Migasiewicz, 1999; Pionk, 1997) as well as athletes of sports games such as handball (Lakomy, 1978; Stawiarski, 1989), volleyball (Stefanicki et al., 1994). Children and youth engaged in swimming are taller and lighter than judokas (Piechaczek et al., 2000).

Comparative characteristics of somatic development (body mass and length) are observed in fencers (Polanowski, 1998), footballers (Bednarski, Kuzmin, 1996; Ozimek, Staszkiewicz, 1999) as well as athletes engaged in winter sports events (Gowarzewski, 1978).

Due to the above one may ascertain that Greco-Roman training sessions positively influence developing body of children. The above is confirmed by numerous studies in the field of sports wrestling (Jiskolski, 1996; Kalina, Jagiełło, 2000 a, 2000 b; Jagiełło et al., 2002).

High heterogeneity of subjects according to indices of body mass is related to this sports event specifics in which there are 7 weight categories (from 55 to $120 \mathrm{~kg}$ ). Due to the above among elite wrestlers one may encounter athletes representing various somatotypes. Sports wrestling is rich in different technical means allowing to decide the outcome of combat. That is why, each athlete irrespective of his body length and mass can form his own style based upon optimum for him techniques.

High variability of Roufier's index in age aspect of Greco-Roman wrestlers is indicative of significant changeability of somatotypes conditioned by various intensities of maturation processes during this period of development as well as sports event specifics (weight categories, selection requirements, etc.). However, the trend of body build transformation into more athletic type which corresponds to the requirements of sports event is quite obvious (after the age of 16).

Numerous studies demonstrate significant correlations between body mass and the level of general physical work capacity (Szopa et al., 1996). These dependences are manifested above all in boys aged 7-14 and indicate achievements of the better results in tests of work capacity by those persons which are characterized by significant involvement of muscular mass. The above studies also demonstrate relationship between general work capacity and body length (relative to boys aged 7-13) as well as prove a positive impact of body length on the efficiency of utilization of long load.

Our studies have failed to prove the above tendency. Correlation analysis of somatic development indices (body mass and length) has failed to show significant dependence of the above indices upon general physical work capacity of examined wrestlers. Thus, in examined group of wrestlers the result of Harvard sample is not solved by mass, length and type of body build. Potential unfavorable impact of body build on the result is statistically insignificant due to compensation by other factors, such as posttraining changes of cardiovascular system.

The above regularity has been confirmed in the works of M. Michałkow et al., (1992) and L. W. Wolkow (1997). They discovered that 
Harvard Step-Test is an adequate measure of general work capacity in personal with sufficient physical preparation due to the fact that the type of body build does not influence significantly upon demonstrated result.

\section{CONCLUSIONS}

1. Greco-Roman wrestlers are characterized by heterogeneity of physical work capacity level with tendency of progressive increase with age. Revealed differences of work capacity potential indicate that coaches should incorporate the principle of training load individualization according to biological capacities of the body. In the process of development the above differences are of irregular character (calm increase from 11 to 15 years and dynamic - from 15 to 18 years).

2. Statistically significant correlations between age, body height and work capacity level were not observed. Therefore, we may assume that Harvard Step-Test is an adequate measure of work capacity in persons with sufficient preparation because the type of body build does not significantly influence upon the result of sample in this case.

3. On the basis of findings we may conclude that Greco-Roman wrestling has a positive influence on developing body. In most cases mean values of examined somatic indices exceed those of children not engaged in sports as well as children practising other sports events. This sports event may be considered as a good means stimulating physical development of children and youth.

4. The age of $11-15$ has turned to be the period of the greatest structural and functional changes in their ontogenesis. During this period the greatest rate of development is peculiar for body mass and height (11-12 years - mass $16 \%$, length $6 \% ; 14-15$ years - mass $25 \%$, length $6 \%$ ), whereas development of work capacity occurs evenly. Along with relative stabilization of the rate of body mass and height development beginning from the age of 16 high rate of work capacity development is observed.

5. High variation of studied features, especially body mass and index (Roufier's) of judokas confirms thesis according to which anthropometric indices do not influence efficiency of competitive activity as it is observed in some sports events, but significantly effect selection of individual techniques.

6. Elaborated scale for estimation of general work capacity should be used for correction of training loads depending on individual peculiarities of work capacity development.

7. Utilized modification of Harvard Step-Test is rather simple and easy to execute test under conditions of training. It allows to execute diagnostics of even great number of athletes within short period of time; amount of load provides its usage practically at all stages of control. Numerous scientific studies as well as practical experience confirm its high diagnostic significance in sports wrestling.

\section{REFERENCES}

Asienkiewicz, R. (1999). Srodowiskowe zróznicowanie sprawnosci fizycznej dzieci szkolnych w wieku 10-13 lat. W: V Miedzynarodowa Konferencja Naukowa Pod honorowym patronatem Prezydenta IAAF dr Primo Nebiolo. Problemy Dymorfizmu Plciowego w Sporcie. Materialy Pokonferencyjne (cz. 5), Katowice. P. 300304.

Astrand, P. O. (1992). Dzieci i mlodziez: zdolnosc wysilkowa, rozwój fizyczny. Sport Wyczynowy, 5-6, 5-9.

Astrand, P. O., Rodahl, D. (1986). Textbook of Work Physiology: Physiological Bases of Exercise. New York; St. Louis: McGraw-Hill.

Bednarski, L., Kuzmin, A. (1996). Cechy morfologiczne, zdolnosci psychomotoryczne i sprawnosc techniczna mlodziezowej kadry Krakowa Berzer pilce noznej. Trener, $4,21-25$.
Berger, J., Bytniewski, M., Wilczewski, A. (1990). Rozwój fizyczny, sprawnosc $i$ wydolnosc dzieci ze srodkowowschodniego makroregionu Polski. AWF w Warszawie, IWFIS w Bialej Podlaskiej.

Burdukiewicz, A., Janusz, A., Pietraszewicz, J. (1997). Ogólna charakterystyka rozwoju wydolnosci fizycznej dzieci i mlodziezy wiejskiej. Populacja dzieci wiejskich w badaniach longitudinalnych czesc III. Studia $i$ monografie. AWF we Wroclawiu. P. 103-121.

Cureton, K. Th. (1954). Physical Training Produces Important Psychological and Physiological Changes. Helsinki: Finnish Association of Sports Medicine. P. 234.

Drozdowski, Z. (1984). Antropologia sportowa: morfologiczne podstawy wychowania fizycznego i sportu. Warszawa-Poznan: PWN.

Ferguson, G. A., Takane, Y. (1997). Analiza statystyczna $w$ psychologii i pedagogice. Warszawa: PWN. 
Fibak, J., Wasilewska-Hładka, S. (1973). Przydatnosc próby harwardzkiej do okreslenia wytrzymalosci kobiet. W: Problemy Medyczne Wychowania Fizycznego. Pamietniki XIV Zjazdu Naukowego Polskiego Towarzystwa Medycyny Sportowej Katowice 9-10 czerwca 1972. Katowice. P. 33-37.

Gowarzewski, Z. (1978). Wysokosc i ciezar finalistów Zimowej Spartakiady Mlodziezy. Sport Wyczynowy, 8, $37-41$.

Jagiełło, W. (2000 a). Przygotowanie fizyczne mlodego sportowca. Biblioteka Trenera. Centralny Osrodek Sportu, Warszawa.

Jagiełło, W. (2000 b). Wydolnosc fizyczna ogólna mlodych judoków na tle rozwoju somatycznego. Roczniki Naukowe AWF Warszawa, t. XXXIX, 91-112.

Jagiełło, W., Wałachowski, M., Kruszewski, A. (2002). Wydolnosc fizyczna ogólna mlodocianych zapasników. Wychowanie Fizyczne i Sport. Wydawnictwo Naukowe PWN. Warszawa. Tom XLVI, Suppl. 1, 1, 187-188.

Jaskólski, E. (1996). Pedagogiczne aspekty rozwoju fizycznego dziecka. AWF we Wroclawiu.

Kalina, R. M., Jagiełło, W. (Eds.) (2000 b). Wychowawcze i utylitarne aspekty sportów walki. Warszawa: Akademia Wychowania Fizycznego Józefa Pilsudskiego.

Kalina, R. M., Jagiełło, W. (2000 a). Zabawowe formy walki w wychowaniu fizycznym i treningu sportowym. Zeszyty Naukowo-Metodyczne. Akademia Wychowania Fizycznego Józefa Pilsudskiego. Warszawa.

Karosz, K. (1993). Sprawnosc fizyczna i budowa ciala dziewczat i chlopców rozpoczynajacych uprawianie gimnastyki. Zeszyty Metodyczno-Naukowe AWF Katowice, 2, 215-224.

Łakomy, Z. (1978). Budowa ciala, wiek, staz sportowy polskich pilkarzy recznych na tle czolówki swiatowej. Sport Wyczynowy, 2.

Łaska-Mierzejewska, T. (1999). Antropologia w sporcie i wychowaniu Fizycznym. Biblioteka Trenera. Centralny Osrodek Sportu. Warszawa.

Laskowski, R., Czerwienski, J. (1997). Ksztaltowanie wydolnosci u judoków wieku rozwojowym. Trening, $2-$ 3, 291-300.

Malinowski, A. (red) (1980). Antropologia fizyczna. Warszawa-Poznan: PWN.

Matwiejew, S., Jagiełło, W. (1997). Judo trening sportowy. Biblioteka Trenera. Warszawa: RCMSzKFiS.
Michałków, M., Mazur, M., Rytasz, W., Urbanska, A., Kosinska, B. (2003). Typ budowy ciala a rezultat uzyskany $\mathrm{w}$ tescie harvardzkim - wyniki badan kandydatów na studia w Instytucie Kultury Fizycznej Uniwersytetu Szczecinskiego. Prace Instytutu Kultury Fizycznej, 8, Uniwersytet.

Migasiewicz, J. (1999). Zróznicowanie Dymorficzne wybranych cech morfofunkcjonalnych kobiet i mezczyzn uprawiajacych rzut dyskiem. W: V Miedzynarodowa Konferencja Naukowa Pod Honorowym Patronatem Prezydenta IAAF Dr Primo Nebiolo. Problemy Dymorfizmu Plciowego w Sporcie. Materialy pokonferencyjne (cz. 5). Katowice. P. 85-89.

Ozimek, M., Staszkiewicz, R. (1999). Ocena prawidlowosci selekcji do podstawowego szkolenia w pilce noznej. Sport Wyczynowy, 5-6, 65-71.

Piechaczek, H., Lewandowska, J., Charzewski, J. (2000). Budowa ciala chlopców i dziewczat uprawiajacych sport plywacki. Wychowanie Fizyczne i Sport, 4, 17-29.

Pionk, A. (1997). Zdolnosci motoryczne i budowa ciala a poziom sportowy lekkoatletów. Trening, 1 (33), 152160. Warszawa: RCMSzKFiS.

Płatonow, W. N. (1990). Adaptacja w sporcie. Warszawa: RCMSzKFiS.

Płatonow, W. N. (1997). Obszczaja teoria podgotowki sportsmienow $w$ olimpijskom sportie. Kijów: Olimpijska literatura.

Polanowski, B. (1998). Zmiany wydolnosci i sprawnosci fizycznej uczniów szkoly sportowej trenujacych szermierke. Wychowanie Fizyczne i Zdrowotne. Wydawnictwa Szkolne i Pedagogiczne, 2, 74-79.

Stawiarski, W. (1989). Wynik a cechy morfologiczne i wiek pilkarzy recznych. Sport Wyczynowy, 3-4, 37-41.

Stefanicki, E., Kosova, A., Flora, K. (1994). Budowa fizyczna mlodych siatkarzy wysokiej klasy. Sport Wyczynowy, 9, 31-39.

Szopa, J., Mleczko, E., Zak, S. (1996). Podstawy antropomotoryki. Polskie Wydawnictwo Naukowe. Warszawa-Kraków.

Trzesniowski, R. (1990). Rozwój fizyczny i sprawnosc fizyczna mlodziezy szkolnej w Polsce. Warszawa: AWF.

Wołkow, L. W. (1997). Tieorija sportiwnogo otbora: sposobnosti, odariennost, talant. Kijów: Wieza.
Received on May 13, 2005

Accepted on June 30, 2005
Wladyslaw Jagiello

Academy of Physical Education Marymoncka str. 34, 00-968 Warsaw

Poland

Tel +48228345417

E-mailwjagiello1@wp.pl 